\title{
Cities as hot stepping stones for tree migration
}

\author{
Qiyao Han $\mathbb{D}^{1}$, Greg Keeffe $\mathbb{D}^{1 凶}$, Paul Caplat ${ }^{2}$ and Alan Simson ${ }^{3}$
}

Cities around the world are promoting tree-planting initiatives to mitigate climate change. The potential of such efforts to assist tree migration has often been overlooked. Due to the urban heat island effect, cities could provide suitable climates for the establishment of outlier populations, serving as propagule sources for poleward tree migration.

npj Urban Sustainability (2021)1:12; https://doi.org/10.1038/s42949-021-00021-1

\section{INTRODUCTION}

Cities around the world are increasingly encouraging and promoting tree-planting initiatives to sequester carbon and mitigate climate change. Picking the right tree in the right place is essential for maintaining the sustainability of urban landscapes $^{1,2}$. As a response to recent climate warming, cities such as Philadelphia, Chicago, and London (Ontario, Canada) have already begun planting more southerly tree species on urban parks, streets, as well as other municipal lands. However, the potential of urban tree planting to assist species migration in a wider landscape has often been overlooked ${ }^{3}$. Due to the urban heat island effect, cities are experiencing a preview of future climates for nearby rural areas, potentially offering a climatic condition suitable for the persistence of outlier populations at higher latitudes than their native ranges. The outlier populations in cities could serve as propagule sources for species' poleward migration under climate change. Moreover, since trees can cool their environment, planting trees in cities can slow the rate of warming, which in turn allows them to grow for decades to reach reproductive maturity for further expansion. Here, we discuss the potential of urban tree plantings to assist the poleward migration of forest trees in temperate and boreal regions. Emphasis is placed on the unique climatic condition that cities could provide for the establishment, growth, and expansion of outlier populations.

\section{THE NEED TO ASSIST TREE MIGRATION}

Climate change is expected to shift the geographical distribution of tree species worldwide ${ }^{4-8}$. Increasing evidence has emerged showing that temperate and boreal forest trees are already moving toward higher latitudes to track suitable climatic conditions, with most of the evidence focusing on Europe and North America ${ }^{9-12}$. However, such movement cannot guarantee their survival, especially if the accessibility of suitable climates is highly constrained by species dispersal capabilities and humancreated barriers $^{13}$. A study of recent climate mechanisms in the 1975-3013 period showed that rates of climate warming were fast across mid-and high-latitude forest biomes, particularly in boreal forests $(1.70 \mathrm{~km}$ per year) and temperate broadleaf and mixed forests $\left(1.07 \mathrm{~km}\right.$ per year) ${ }^{14}$. These estimates were about 10 times faster than the rate of tree migration by long-distance dispersal $(\sim 100-200 \mathrm{~m} \text { per year })^{15}$. It is projected that due to dispersal limitation, most of the wind- and animal-dispersed plant species in Europe will not be able to catch up with future climate change ${ }^{16}$.
In western North America, trees have already lagged behind their optimal climatic niches by $\sim 130 \mathrm{~km}$ in latitude or $60 \mathrm{~m}$ in elevation on average ${ }^{17}$. The stress induced by rapid climate warming will be exacerbated by the negative effect of extreme weather events (e.g., heat waves, drought, floods, and storms), which constrain the establishment and spread of tree species. The consequent decoupling between climate shifts and species migrations may result in species extinction ${ }^{18}$, as happened to a species of spruce, Picea critchfieldii, in eastern North America after the Last Glacial Maximum $^{19}$

Despite the pessimistic predictions, empirical studies of postglacial recolonization indicate that trees in boreal and temperate regions may not necessarily lag behind climate change, as species migration can be facilitated by the persistence of outlier populations in advance of their main ranges ${ }^{20}$. Rapid range shifts of boreal and temperate trees occurred following the retreat of ice sheets after the last glacial period ${ }^{21}$. Molecular evidence suggests that such range shifts were achieved by local dispersal from small, isolated populations occupying high-latitude microrefugia, where climates were favourable for their persistence outside of main ranges during the glacial period ${ }^{22}$. A well-documented example is ice-free refugia in northern Scandinavia, which supported the survival and expansion of conifer trees after the Last Glacial Maximum ${ }^{23}$. Recent models have also highlighted the favourable effects of outlier populations on poleward range shifts ${ }^{24}$. The role of outlier populations in the past may have an analogy under future climate change, as outlier populations not only can occur naturally as relicts of past climates but also could result from anthropogenic planting. Even a small number of trees planted far beyond their native range limit can be sufficient to establish naturalized populations ${ }^{25}$.

\section{URBAN HEAT ISLANDS AS STEPPING STONES}

Cities are already ahead of their surroundings in terms of climate warming, therefore potentially offering suitable climate conditions for the establishment of outlier populations (Fig. 1). Urban areas tend to have higher temperatures than their surrounding rural areas as if a warmer city air lies in a "sea" of cooler rural air ${ }^{26}$. This phenomenon has been commonly observed and investigated around the world, known as the urban heat island effect ${ }^{27}$. Generally, the urban heat island effect is an "inadvertent" modification of local climates during urbanization, caused by anthropogenic modifications of the landscape, anthropogenic 


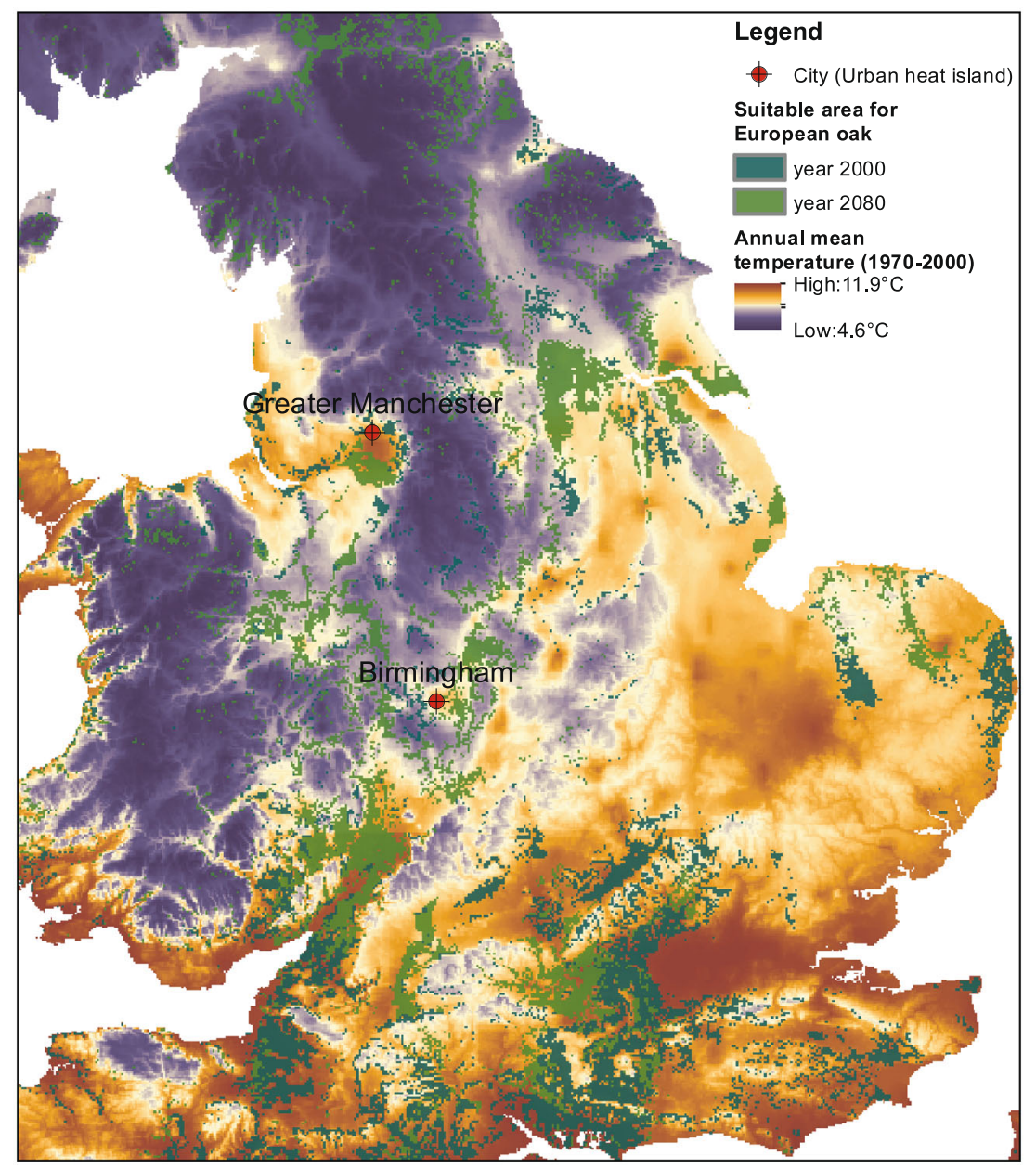

Fig. 1 Example of the urban heat island effect. Urban heat islands in Greater Manchester and Birmingham are analogous to temperatures in the main ranges of European oaks (Quercus robur) in southern England. Climate data were obtained from the WorldClim Version2 ${ }^{55}$. Green colours represent areas suitable for European oaks under present and future climates (obtained from http://data.europa.eu/89h/55e584aaca3b-429a-bc99-dfc1f936ea81).

heat emissions, and the physical properties of buildings and other urban structures ${ }^{28}$.

Although the urban heat island effect is a local phenomenon with negligible impact on global warming ${ }^{29}$, its intensity and effect may represent harbingers of future climates. Observation of 419 big cities around the world showed that the average annual surface temperature difference between urban and rural areas can be as much as $1.5 \pm 1.2^{\circ} \mathrm{C}$ during the day and $1.1 \pm 0.5^{\circ} \mathrm{C}$ at night $^{30}$. In contrast, the observed global mean surface temperature has increased by $\sim 0.87^{\circ} \mathrm{C}$ above $1850-1900$ levels $^{31}$. Such warming is expected to reach $1.5^{\circ} \mathrm{C}$ between 2030 and 2052 if it continues to increase at the current rate of about $0.2{ }^{\circ} \mathrm{C}$ per decade. In Baltimore, for example, urban-rural differences in air temperature are similar to projected climate changes over the next $50-100$ years $^{32}$. Higher temperatures in urban areas affect species' living by stimulating their photosynthetic activity and extending growing season length ${ }^{33}$. Indeed, urban trees have been observed to grow faster than their counterparts in rural surroundings ${ }^{34-36}$. Although tree growth is driven by a combination of multiple biotic and abiotic factors (e.g., local climate, $\mathrm{CO}_{2}$ concentration, pollution, light regime, interspecific competition, soil condition, nutrient, and water availability), the higher growth rates of urban trees seem to be closely related to the urban heat island effect.

Planting outlier populations in urban heat islands is expected to provide a substantial head start on poleward range shifts. Taking temperate broadleaf forests as an example, if the current rate of global warming continues, forest trees would need to move at least $107 \mathrm{~km}$ poleward over the next 100 years ${ }^{14}$. Given their migration rates $\left(<100 \mathrm{~m}\right.$ per year) during the early Holocene ${ }^{37}$, trees are likely to lag behind climate change by at least $97 \mathrm{~km}$ in the coming century without considering habitat fragmentation. On the other hand, daytime surface temperatures in temperate cities are as much as $0.46-1.43^{\circ} \mathrm{C}$ higher than in their surrounding rural areas ${ }^{38}$, which means that outlier populations in the cities could be closer to their future ranges by about $59-182 \mathrm{~km}$ than their native ranges with analogous climates (taking into account a $0.87^{\circ} \mathrm{C}$ increase in urban-rural temperature differences as being equivalent to a $111 \mathrm{~km}$ poleward movement of species' optimal climatic conditions) ${ }^{39}$. It is, therefore, possible to shorten or even eliminate migration lags in tree species by planting outlier populations in cities.

\section{OUTLIER POPULATIONS IN URBAN HEAT ISLANDS}

Cities have a long history of establishing outlier populations, either intentionally or accidentally ${ }^{40,41}$. Urban green spaces such as forest remnants, public parks, and gardens have great potential to receive and accommodate translocated tree species. During the last 200 years, international exchanges of plant material among botanic gardens have played a considerable role in the development of the alien flora in Central Europe ${ }^{42}$. An investigation of 357 

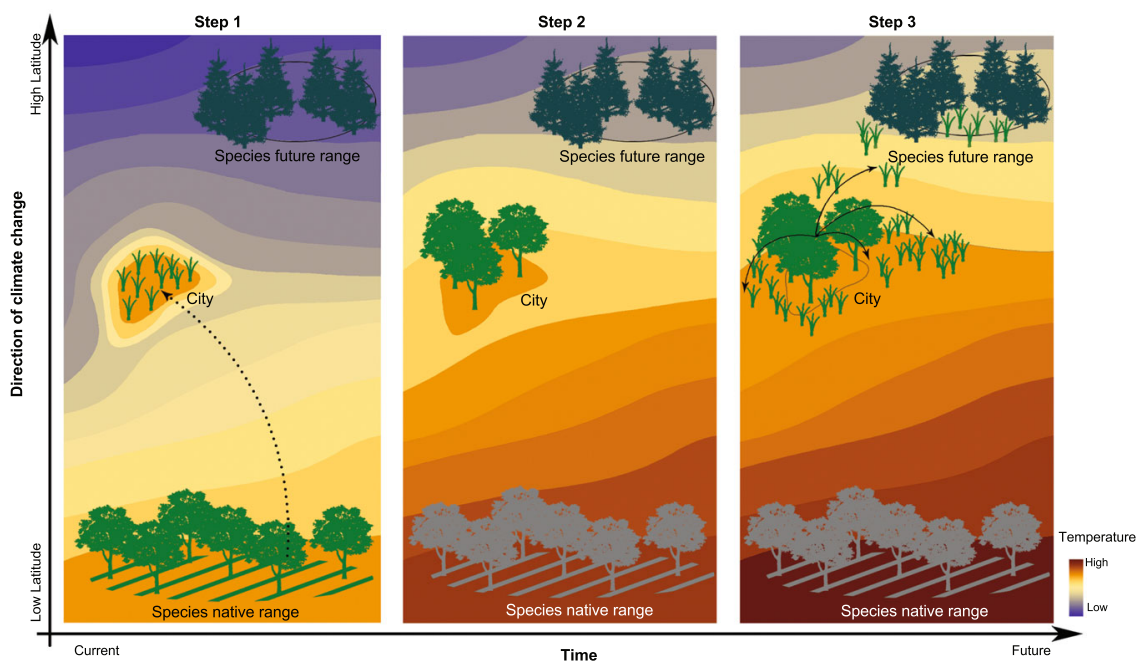

Fig. 2 Illustration of using cities as stepping stones for poleward tree migration. Step (1): Seeds and seedlings collected from their native ranges are used to establish outlier populations in a higher latitude city where the climate is suitable. Step (2): Assuming the first step is successful, translocated species will grow and reach reproductive maturity, accompanied by their ability to cool the city. Step (3): Seeds produced by the outlier populations in the city are then dispersed to surrounding rural areas to establish naturalized populations, or are collected and planted in a more poleward city if the climate warms faster than projected, repeating steps (1) and (2).

European plant species showed that $73 \%$ of them have been moved into nurseries and gardens hundreds or even thousands of kilometres north of their natural range limits ${ }^{43}$. In the eastern United States, southern species planted in northern urban areas as ornamental plants are expected to speed the process of tree migration to a rate of $1 \mathrm{~km}$ per year ${ }^{11}$.

Trees planted in urban heat islands can slow the rate of warming, leading to more stable microclimate conditions in urban areas relative to surrounding rural areas. Trees cool their environment through shading, evapotranspiration, and solar radiation reflection ${ }^{44}$. In the context of global warming, the cooling effect of trees could partially or fully offset increases in urban background climate. For example, in Greater Manchester, a $10 \%$ increase of tree cover in high-density residential areas or town centres can counterbalance projected increases in maximum surface temperature due to climate change in the 2050s relative to $1961-1990^{45}$. The combined effect of urban background climate and the tree cooling effect has been observed in urban parks, which experience growing seasons longer than rural areas but shorter than nearby urban areas ${ }^{46}$. The relatively stable microclimate conditions in cities could allow trees to grow for a few decades to reach reproductive maturity.

Reproductive populations could then serve as propagule sources, from which species spread into surrounding areas and subsequently develop naturalized populations as climatic conditions allowed ${ }^{47}$. The process of range expansion can be supported by urban green spaces, such as private gardens, agricultural islands, roadside hedges, and copses ${ }^{48}$. These man-made landscapes could work as a series of habitat islands that provide stopover points, food, and shelters for the movement of seed dispersal agents (such as crows, jays, and nutcrackers) from urban to rural areas.

\section{USING CITIES AS STEPPING STONES}

Establishing outlier populations in cities can be regarded as a form of assisted migration (also called managed relocation or assisted colonization), which refers to the intentional translocation of species and populations outside their historic ranges to facilitate their range shifts under climate change ${ }^{49}$. Here, cities are perceived as 'hot' stepping stones for poleward migration, whilst species' future distributions are viewed as moving targets, which can be achieved by successively establishing outlier populations in cities along latitudinal gradients (Fig. 2). The 'climate analogues' approach developed by $\mathrm{CCAFS}^{50}$ can help identify cities that have similar climatic conditions with those of species' native ranges at lower latitudes. Besides, the outlier populations established in cities can provide additional nursery capacity for assisted migration in local and regional spheres. For example, public parks and botanic gardens could serve as nurseries to test and accommodate translocated seeds and seedlings, providing a future supply of trees for efforts of assisted migration in nearby rural areas. Such efforts also avoid some problems associated with planting species outside their native ranges: not only because cities could provide them with extensive horticultural expertise, regular care, and record-keeping, but also because cities could offer real-world laboratories for ecologists, foresters, and managers to monitor and minimize the invasiveness of translocated species in their new environments, as well as their potential for creating pest problems ${ }^{51}$, before the implementation of largescale tree plantings.

It should be noted urban tree plantings that aim to assist tree migration will be able to reduce losses of ecosystem services in urban environments due to climate change ${ }^{52}$. Trees are a vital part of urban ecosystems. Maintaining and enhancing the long-term health of trees is essential for urban forests so that they can continue to provide ecosystem services, such as climate regulation, air purification, and carbon sequestration. The rate of recent climate change has exceeded the capacity of some native trees in urban environments to adapt, leading to increased mortality and susceptibility to fungal disease, insects, and other pathogens. One example is the native trees in the city of Bellevue, Washington, including western red cedar, western hemlock, and Douglas fir, which are experiencing a higher mortality rate due to drought stress. Efforts of assisted migration in urban areas can help establish new and better-adapted urban forests that support the sustainability of urban ecosystems.

Nevertheless, the success of assisted migration in urban areas will depend on the close cooperation among urban foresters, biologists, urban designers, and landscape architects. Besides urban heat island effects, intensive human activities in cities often result in harsh growing conditions for trees, which include altered hydrology and soil, air quality, invasive species, and heavy anthropogenic disturbances ${ }^{2}$. These conditions might have 
negative effects on the outcome of the practice and thus need to be considered in efforts to establish outlier populations. Another important consideration will be the selection of seed provenance. Urban forests often have high risks of inbred effects and genetic narrowing. To maintain the genetic diversity of outlier populations, translocated seeds and seedlings should be selected by collaborating with experts in provenance selection. Further research is also required to enhance landscape connectivity to facilitate seed dispersal and accelerate the speed of colonization in and around urban areas ${ }^{53}$. Good understandings of the topology of urban forests and seed dispersal networks are needed to identify 'hub' woodlands where seed dispersal events are concentrated and outlier populations should be initiated ${ }^{54}$. Finally, to better share urban spaces with outlier populations, the practice of assisted migration must be assimilated within urban planning and design projects, which treat urban landscaping as an experimental substrate to study the persistence and invasiveness of translocated species whilst maintaining and improving ecosystem services for human beings. Gardeners need to think beyond beauty when selecting species and more on the potential of horticulture to serve as a route of assisted migration.

Received: 7 September 2020; Accepted: 23 January 2021; Published online: 27 May 2021

\section{REFERENCES}

1. Willis, K. J. \& Petrokofsky, G. The natural capital of city trees. Science 356, 374-376 (2017).

2. Fontaine, L. C. \& Larson, B. M. H. The right tree at the right place? Exploring urban foresters' perceptions of assisted migration. Urban For. Urban Green. 18, 221-227 (2016).

3. Barnosky, A. D. et al. Merging paleobiology with conservation biology to guide the future of terrestrial ecosystems. Science 355, eaah4787 (2017).

4. Nolan, C. et al. Past and future global transformation of terrestrial ecosystems under climate change. Science 361, 920-923 (2018).

5. Pecl, G. T. et al. Biodiversity redistribution under climate change: impacts on ecosystems and human well-being. Science 355, eaai9214 (2017).

6. Walther, G.-R. et al. Ecological responses to recent climate change. Nature 416, 389-395 (2002).

7. Araújo, M. B., Alagador, D., Cabeza, M., Nogués-Bravo, D. \& Thuiller, W. Climate change threatens European conservation areas. Ecol. Lett. 14, 484-492 (2011).

8. Rehfeldt, G. E., Crookston, N. L., Warwell, M. V. \& Evans, J. S. Empirical analyses of plant-climate relationships for the Western United States. Int. J. Plant Sci. 167, 1123-1150 (2006).

9. Tomiolo, S. \& Ward, D. Species migrations and range shifts: a synthesis of causes and consequences. Perspect. Plant Ecol. Evol. Syst. 33, 62-77 (2018).

10. Cavanaugh, K. C. et al. Poleward expansion of mangroves is a threshold response to decreased frequency of extreme cold events. Proc. Natl. Acad. Sci. USA 111, 723-727 (2014).

11. Woodall, C. W. et al. An indicator of tree migration in forests of the eastern United States. For. Ecol. Manag. 257, 1434-1444 (2009).

12. Walther, G. R. et al. Palms tracking climate change. Glob. Ecol. Biogeogr. 16, 801-809 (2007).

13. Miller, K. M. \& McGill, B. J. Land use and life history limit migration capacity of eastern tree species. Glob. Ecol. Biogeogr. 27, 57-67 (2018).

14. Ordonez, A., Williams, J. W. \& Svenning, J. C. Mapping climatic mechanisms likely to favour the emergence of novel communities. Nat. Clim. Chang. 6, 1104-1109 (2016).

15. Lazarus, E. D. \& McGill, B. J. Pushing the pace of tree species migration. PLOS ONE 9, e105380 (2014).

16. Cunze, S., Heydel, F. \& Tackenberg, O. Are plant species able to keep pace with the rapidly changing climate? PLOS ONE 8, e67909 (2013).

17. Gray, L. K. \& Hamann, A. Tracking suitable habitat for tree populations under climate change in western North America. Clim. Change 117, 289-303 (2013).

18. Petit, R. J., Hu, F. S. \& Dick, C. W. Forests of the past: a window to future changes. Science 320, 1450-1452 (2008).

19. Jackson, S. T. \& Weng, C. Late Quaternary extinction of a tree species in eastern North America. Proc. Natl Acad. Sci. USA 96, 13847-13852 (1999).

20. Mosblech, N. A. S., Bush, M. B. \& van Woesik, R. On metapopulations and microrefugia: Palaeoecological insights. J. Biogeogr. 38, 419-429 (2011).
21. Davis, M. B. \& Shaw, R. G. Range shifts and adaptive responses to Quaternary climate change. Science 292, 673-679 (2001).

22. Hu, F. S., Hampe, A. \& Petit, R. J. Paleoecology meets genetics: deciphering past vegetational dynamics. Front. Ecol. Environ. 7, 371-379 (2009).

23. Parducci, L. et al. Glacial survival of boreal trees in northern Scandinavia. Science 335, 1083-1086 (2012).

24. Snell, R. S. \& Cowling, S. A. Consideration of dispersal processes and northern refugia can improve our understanding of past plant migration rates in North America. J. Biogeogr. 42, 1677-1688 (2015).

25. Lopez, J. Single planting creates expanding naturalized population of quercus palustris far from its native range limit. Rhodora 120, 143-153 (2018).

26. Varquez, A. C. G. \& Kanda, M. Global urban climatology: a meta-analysis of air temperature trends (1960-2009). npj Clim. Atmos. Sci. 1, 32 (2018).

27. Stewart, I. D. \& Oke, T. R. Local climate zones for urban temperature studies. Bull. Am. Meteorol. Soc. 93, 1879-1900 (2012).

28. Rizwan, A. M., Dennis, L. Y. C. \& Liu, C. A review on the generation, determination and mitigation of Urban Heat Island. J. Environ. Sci. 20, 120-128 (2008).

29. Parker, D. E. Urban heat island effects on estimates of observed climate change. WIREs Clim. Change 1, 123-133 (2010).

30. Peng, S. et al. Surface urban heat island across 419 global big cities. Environ. Sci. Technol. 46, 696-703 (2012).

31. IPCC. Global Warming of $1.5^{\circ} \mathrm{C}$ (World Meteorological Organization, 2018).

32. George, K., Ziska, L. H., Bunce, J. A. \& Quebedeaux, B. Elevated atmospheric $\mathrm{CO}_{2}$ concentration and temperature across an urban-rural transect. Atmos. Environ. 41, 7654-7665 (2007).

33. Dallimer, M., Tang, Z., Gaston, K. J. \& Davies, Z. G. The extent of shifts in vegetation phenology between rural and urban areas within a human-dominated region. Ecol. Evol. 6, 1942-1953 (2016).

34. Dahlhausen, J., Rötzer, T., Biber, P., Uhl, E. \& Pretzsch, H. Urban climate modifies tree growth in Berlin. Int. J. Biometeorol. 62, 795-808 (2018).

35. Pretzsch, $\mathrm{H}$. et al. Climate change accelerates growth of urban trees in metropolises worldwide. Sci. Rep. 7, 15403 (2017).

36. Searle, S. Y. et al. Urban environment of New York city promotes growth in northern red oak seedlings. Tree Physiol. 32, 389-400 (2012).

37. McLachlan, J. S., Clark, J. S. \& Manos, P. S. Molecular indicators of tree migration capacity under rapid climate change. Ecology 86, 2088-2098 (2005).

38. Chakraborty, T. \& Lee, X. A simplified urban-extent algorithm to characterize surface urban heat islands on a global scale and examine vegetation control on their spatiotemporal variability. Int. J. Appl. Earth Obs. Geoinf. 74, 269-280 (2019).

39. Wang, K., Sun, J., Cheng, G. \& Jiang, H. Effect of altitude and latitude on surface air temperature across the Qinghai-Tibet plateau. J. Mt. Sci. 8, 808-816 (2011).

40. Kendal, D., Williams, N. S. G. \& Williams, K. J. H. A cultivated environment: exploring the global distribution of plants in gardens, parks and streetscapes. Urban Ecosyst. 15, 637-652 (2012).

41. Almas, A. D. \& Conway, T. M. The role of native species in urban forest planning and practice: a case study of Carolinian Canada. Urban For. Urban Green. 17, 54-62 (2016).

42. Galera, H. \& Sudnik-Wócikowska, B. Central European botanic gardens as centres of dispersal of alien plants. Acta Soc. Bot. Pol. 79, 147-156 (2010).

43. Van der Veken, S., Hermy, M., Vellend, M., Knapen, A. \& Verheyen, K. Garden plants get a head start on climate change. Front. Ecol. Environ. 6, 212-216 (2008).

44. Smithers, R. J. et al. Comparing the relative abilities of tree species to cool the urban environment. Urban Ecosyst. 21, 851-862 (2018).

45. Gill, S. E., Handley, J. F., Ennos, A. R. \& Pauleit, S. Adapting cities for climate change: The role of the green infrastructure. Built Environ. 33, 115-133 (2007).

46. Zipper, S. C. et al. Urban heat island impacts on plant phenology: intra-urban variability and response to land cover. Environ. Res. Lett. 11, 054023 (2016).

47. Woodall, C. W., Nowak, D. J., Liknes, G. C. \& Westfall, J. A. Assessing the potential for urban trees to facilitate forest tree migration in the eastern United States. For. Ecol. Manage. 259, 1447-1454 (2010).

48. Horta, M. B. et al. Functional connectivity in urban landscapes promoted by Ramphastos toco (Toco Toucan) and its implications for policy making. Urban Ecosyst. 21, 1097-1111 (2018).

49. Marris, E. Forestry: planting the forest of the future. Nature 459, 906-908 (2009).

50. Harvey, B. et al. Climate Change Communication and Social Learning-Review and Strategy Development for CCAFS (CCAFS, 2012)

51. Farrell, C., Szota, C. \& Arndt, S. K. Urban plantings: 'Living laboratories' for climate change response. Trends Plant Sci. 20, 597-599 (2015).

52. Millar, C. I. \& Stephenson, N. L. Temperate forest health in an era of emerging megadisturbance. Science 349, 823-826 (2015).

53. Hodgson, J. A., Thomas, C. D., Dytham, C., Travis, J. M. J. \& Cornell, S. J. The speed of range shifts in fragmented landscapes. PLOS ONE 7, e47141 (2012).

54. Han, Q. \& Keeffe, G. Mapping the flow of forest migration through the city under climate change. Urban Plan. 4, 139-151 (2019). 
55. Fick, S. E. \& Hijmans, R. J. WorldClim 2: new 1-km spatial resolution climate surfaces for global land areas. Int. J. Climatol. 37, 4302-4315 (2017).

\section{ACKNOWLEDGEMENTS}

Q.H. is funded by a joint scholarship from China Scholarship Council and Queen's University Belfast.

\section{AUTHOR CONTRIBUTIONS}

Q.H., G.K. and P.C. proposed the initial idea of the paper. Q.H. drafted the manuscript. G.K., P.C. and A.S. revised the manuscript. G.K. supervised the project.

\section{COMPETING INTERESTS}

The authors declare no competing interests.

\section{ADDITIONAL INFORMATION}

Correspondence and requests for materials should be addressed to G.K.

Reprints and permission information is available at http://www.nature.com/ reprints
Publisher's note Springer Nature remains neutral with regard to jurisdictional claims in published maps and institutional affiliations.
Open Access This article is licensed under a Creative Commons Attribution 4.0 International License, which permits use, sharing, adaptation, distribution and reproduction in any medium or format, as long as you give appropriate credit to the original author(s) and the source, provide a link to the Creative Commons license, and indicate if changes were made. The images or other third party material in this article are included in the article's Creative Commons license, unless indicated otherwise in a credit line to the material. If material is not included in the article's Creative Commons license and your intended use is not permitted by statutory regulation or exceeds the permitted use, you will need to obtain permission directly from the copyright holder. To view a copy of this license, visit http://creativecommons. org/licenses/by/4.0/.

(c) The Author(s) 2021 